THURSDAY, JANUARY I4, I9I5.

\section{THE WAR.}

THE war drags on; and we are learning to understand the mentality of the German race more completely. It is being revealed in various forms. The policy always adopted by the bully, of attempting to terrorise by attack on defenceless persons, is shown by the shelling of the wateringplaces of Yorkshire, resulting in the murder (for that is the only word which fits the case) of Io3 $_{3}$ harmless people. "Murder" should certainly have been the verdict, although it was disallowed by the coroner; for although the commanders of the German vessels may not yet be known by name, a verdict of murder would have rendered them subject, when captured, to trial by a British jury. The cowardly and murderous onslaught has led, we are told, to rejoicings in Berlin. It is as we feared; the German nation has lost its moral perspective. They may rest assured, however, that there will be no similar reprisals on the side of the Allies. We do not revenge ourselves on innocent women and children.

It was scarcely worth while, perhaps, for the French universities and British men of letters and science to have replied to the self-named "intellectuals" of Germany. Neutral countries have already made up their minds from the perusal of official documents, not the least important being those from German sources, that the war is one of pure aggression on the part of the Germans. We hear from Switzerland, from America, and from Scandinavia that the public in these countries now pay no attention to German polemic literature. If they had conceivably had any case, they have given it away by their inhuman acts, which have raised a sentiment of disgust in every civilised mind.

We look with contemptuous amusement at the childish renunciation of foreign honours by our Teutonic colleagues in science. That is even the attitude of some of their own countrymen; Prof. Verworn, of Bonn, writing in the Berliner Tageblatt, describes it as unworthy of German men of science, and Profs. Waldeyer, Martin, and Orth have protested against the foolish conduct of their countrymen. We can only shrug our shoulders and say that the loss is theirs, not ours.

We have also been disillusioned by the words of the well-known Celtic scholar, Prof. Kuno Meyer, late of Liverpool University, now of Berlin, who has acted, and is acting, as an agent of the Prussian Government in attempting to excite the No. 2359, VOL. 94] feelings of Nationalist Ireland and of American Irish in favour of Germany. Here is a man, eminent in his own subject, speaking English without an accent, who has spent thirty years of his life in an English university, a man who has (or had) many intimate friends in this country and has been received in many English households as a friend, turning out to be a dastardly enemy. Savages have a code that, after breaking bread in a man's house, it is treacherous to war against him; not so Prof. Kuno Meyer. This is evidently another instance of "Kultur." It behoves us to treat with suspicion all naturalised aliens of Teutonic extraction; and yet we know, alas! that in doing this, we are acting unjustly in some cases. But the individual, in these days, must suffer for the crimes of his countrymen. It is such instances as these which make the Allies determined that such a race must be deprived of power to do further mischief, whatever be the cost in life and money.

Some correspondence has appeared in the Press as to the relative merits of German contributions to science, as compared with the achievements of members of other races. The discussion is perhaps a useful one; for there is little doubt that the German estimate of the scientific ability of their own people is a much exaggerated one. The statemient made in a previous issue of Nature (October 8) that German science has not been remarkable for originality appears to meet with general assent. We in England have been always more intent on welcoming a discovery than in inquiring into the nationality of the discoverer; indeed, it is a common saying that science is international. But we are beginning to revise our verdict. Prof. Karl Pearson, Prof. Sayce, and Sir E. Ray Lankester have shown that Germany has played only a small part in inception of scientific truths, although by organisation she has greatly extended their application. Huxley and Bywater held this view, each as regards his own subject; and it appears to be shared by geologists, physicists, and chemists. "Ausarbeiten" is the goal of the Germans; the inventive faculty has not been their strong point. Perhaps a mixed race gains in original ability; both flint and steel are necessary to produce a spark. But one thing the German man of science knows how to do well - to exalt the achievements of his nation, often by ignoring that of others. This has probably been done in many cases without intention; it appears to be one way in which German patriotism manifests itself.

Dr. Hugo Schweizer, an Americanised German, $\mathrm{X}$ 
writing in the Popular Science Monthly (December issue), maintains the thesis that the development of science owes much, if not all, to the stimulus of the demands of Prussian military requirements. Naturally, his examples refer entirely to technical applications of science. And here, again, if they are analysed, it can be shown that the development of which he boasts is due to concentrated and organised effort; of the starting-points of the manufactures which he cites, few are of German origin. They have been appropriated and worked out, no doubt, in order to place the materials of war at the disposal of the German Army; but it is not proved that the necessities of peace are not more effective as a stimulus to progress than those of war. To take only one instance, it is probable that sooner or later all our railways will be electrified; but that would not suit military exigencies; each train must have an independent motive power; and so long as German militarism persists, we may reckon that German railways, at least, will not be run by the electric current.

The aims of science are the antitheses of those of war. It is the object of pure science to attempt to know and correlate natural phenomena, and its devotees are inspired by an insatiable curiosity; it is the object of applied science to make use of that knowledge for the benefit of mankind. To degrade its applications to the destruction of life and property is the most unscientific act of which a people can be guilty.

\section{LORD AVEBURY: BANKER AND NATURALIST.}

Life of Sir John Lubbock, Lord Avebury. By H. G. Hutchinson. Two vols. Vol. i., pp. xiv + 338. Vol. ii., pp. $x+334$. (London: Macmillan and Co., Ltd., 19r4.) Price 3os. net, 2 vols.

CIR John Lubbock was a notable figure in the $D$ period of our scientific history which saw the birth and development of evolutionary theory. If the part he played was not as weighty as that of Lyell, of "Huxley, and of Hooker, it was even more effective. For he spoke as a man of affairs and with convinced sincerity; and if he was "a great banker amongst scientists" so much the better. Like Spottiswoode, he could show that a scientific mind was capable of business success; both, in fact, were members of the X Club, that mysterious body, impossible of successor, which was said "to govern scientific affairs," and "not to do it badly"; Lubbock was, indeed, its last surviving member.

Biography is an art in which any great measure NO. 2359, VOL. 94] of success is rare. For it demands that the subject should reveal itself while we remain almost unconscious of the hand of the artist. Mr. Hutchinson is more artless, and rivals Boswell in the feat of giving us himself as well. He could not draw on letters, the biographer's best resource; to Lubbock, he explains, "exposure of the holy sanctities of his being would have been impossible." Apology seems unnecessary, then, for Lubbock's "attending the services, at the village church" and reading his Bible; though Huxley did the latter and to some purpose. The explanation is found in the belief "that there was some room, after all, among the atoms for the spirits." After this it is pleasant to know that 40,000 people attended the last race meeting in his father's park at High Elms; amongst them were the Archbishop of Canterbury and the Lord Chancellor, evidently spirits. Picking holes is rather futile. But two statements, at any rate, catch the eye as perplexing. Sir Gabriel Stokes (i., 85) is made to say that the chance of laying the first Atlantic cable was "only $\left(\frac{19}{2}\right)_{20}=35^{\circ}{ }^{\circ}$, or about 2 to I against it"; obviously this should be $\left(\frac{19}{2}\right)^{20}$, and one wonders who and what was the "Consul D'État" (ii., 23) whom Lubbock went to see in Paris.

Mr. Hutchinson says reasonably enough that to anyone who did not know Lubbock's "serene, unruffled calm" one might easily conceive him as "an animated hurricane." Even to read the life is like travelling in an express train with but a blurred impression of successive landmarks. Only one of his many personalities needs treatment here, and that requires a little more justice than it has always received.

Lubbock's father was a mathematician of some repute, and treasurer of the Royal Society when the Duke of Sussex was little more than nominal president. His mother notes that at the age of four "His great delight is in insects." He was some four years at Eton, where he was thought "exceedingly inaccurate," but that must be taken in an Etonian sense. "Against the advice of his tutor he read some natural history and geology." At the age of fourteen his father was obliged to make use of him in the bank. "He and I with a worthy old clerk carried on the business." Lubbock thought that "beginning so" early gave him an instinct for business," and well it might. At the age of nineteen he made a minute time-table for his day from half-past six to midnight. Science and literature fill the compartments; 9.30 to Io was devoted to "sermons (if I read them any later they invariably send me to sleep):" Such a discipline would have sterilised most men. But his neighbour Darwin gave him a wider training. 